\title{
A CASE OF GIANT OVARIAN CYST MANAGED SUCCESSFULLY THROUGH LAPAROSCOPIC SURGERY
}

\author{
Su-Kon Kim, MD, Jong-Soo Kim, MD, Choong-Hak Park, MD, Jin-Wan Park, MD \\ Department of Obstetrics and Gynecology, Dankook University College of Medicine, Cheonan, Korea
}

Mucinous ovarian tumors account for $15 \%$ all ovarian neoplasms, of which giant variants rarely occur. Recently huge ovarian cysts (more than $12 \mathrm{~kg}$ ) are now rarely seen because of the development in health care systems and education. The patient is 26 -yearold nulligravida female who presented with abdominal distension. A laparoscopic left salpingo-oophorectomy was performed. Laparoscopic approach to giant ovarian cyst may be difficult regarding the risk of cyst rupture and limited working space. To reduce the limitations of the laparoscopy, we performed laparoscopy after aspirating the cystic contents. During laparoscopy, abdominal cavity was explored by the scope. Cyst contained about $53 \mathrm{~L}$ of fluid. The histopathologic examination revealed a borderline mucinous tumor of the left ovary. Laparoscopic excision of giant ovarian cyst seems to be safe and applicable treatment modality.

Keywords: Ovary; Cyst; Laparoscopy

Laparoscopic approach is more advantageous over laparotomy, considering better cosmetic results, lesser blood loss, lesser pain and analgesic requirement, faster recovery, and shorter hospitalization time [1]. Laparoscopic approach to giant ovarian cyst, in cases when the cysts' sizes exceed to the umbilicus, may be difficult regarding the risk of cyst rupture and limited working space [2]. However, if the laparotomy is chosen as the operative treatment, a larger incision is required to excise the cyst. We present a case of laparoscopic extirpation of a giant ovarian cyst.

\section{Case Report}

A 26-year-old woman was referred to our department for a giant abdominal mass in July 2011. She was single and nulliparous female who presented with a gradually increasing abdominal swelling first noticed 4 years ago. Due to the huge mass she was unable to walk and had anorexia and weight gain. At admission, the emaciated patient weighted $120 \mathrm{~kg}$, had a body height of 177 $\mathrm{cm}$ and abdominal girth at the level of the umbilicus was $190 \mathrm{~cm}$ (Fig. 1). There was no history of colicky pain fainting attacks, vomiting or other gastrointestinal attacks. She had no previous history of any illnesses, allergies or operations.

On abdominal examination, abdomen was grossly distended engorged veins present, fluid thrill was present. There were no abnormalities in hematologic and biochemical data including cancer biomarkers CA-125, CA 19-9, and carcinoembryonic antigen.

On ultrasonography, a huge, multilocular cystic tumor with low echogenic content was found (Fig. 2). There were no papillary or solid parts of associated with the wall or septa, and no ascites. She could not fit into the computed tomography machine due to the giant abdominal mass. After consultation with the anesthesiology and cardiology teams, the patient was placed in a semiFowler's position in the operating room due to dyspnea, general anesthesia and endotracheal tube intubation was performed. After

Received: 2012.3.27. Accepted: 2012.5.15. Corresponding author: Jin-Wan Park, MD Department of Obstetrics and Gynecology, Dankook University College of Medicine, 119 Dandae-ro, Dongnam-gu, Cheonan 330-714, Korea

Tel: +82-41-550-6159 Fax: +82-41-556-3878

E-mail: parkdkog@naver.com

This is an Open Access article distributed under the terms of the Creative Commons Attribution Non-Commercial License (http://creativecommons.org/licenses/ by-nc/3.0/) which permits unrestricted non-commercial use, distribution, and reproduction in any medium, provided the original work is properly cited.

Copyright $\odot$ 2012. Korean Society of Obstetrics and Gynecology 


\section{KOREAN JOURNAL OF OBSTETRICS \& GYNECOLOGY}

Su-Kon Kim, et al. Giant ovarian cyst, laparoscopic surgery

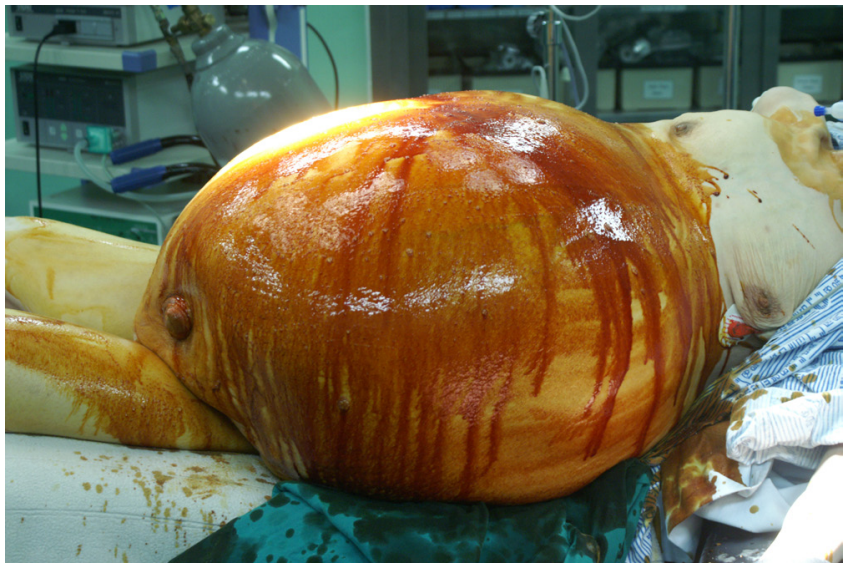

Fig. 1. Patient with a giant abdominal mass.

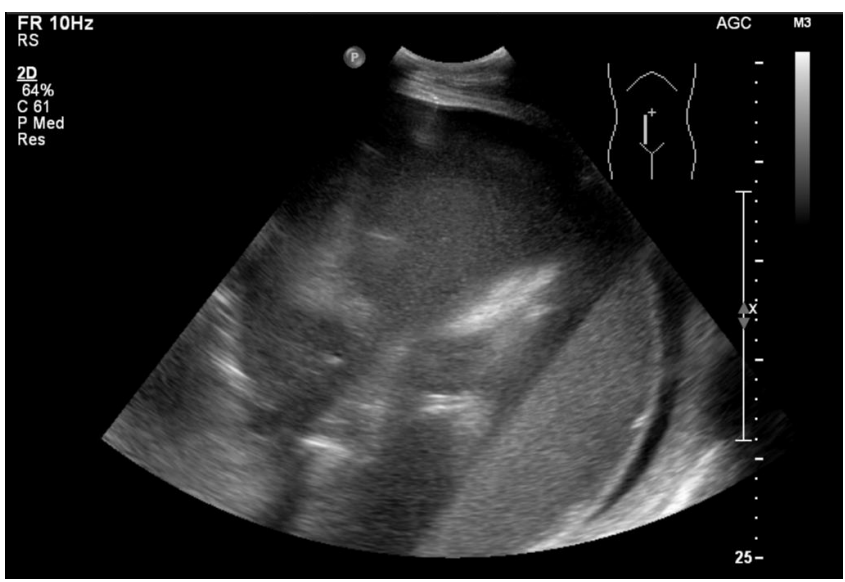

Fig. 2. Bulky complex echoic mass lesion replaced from epigastric area to pelvic cavity.

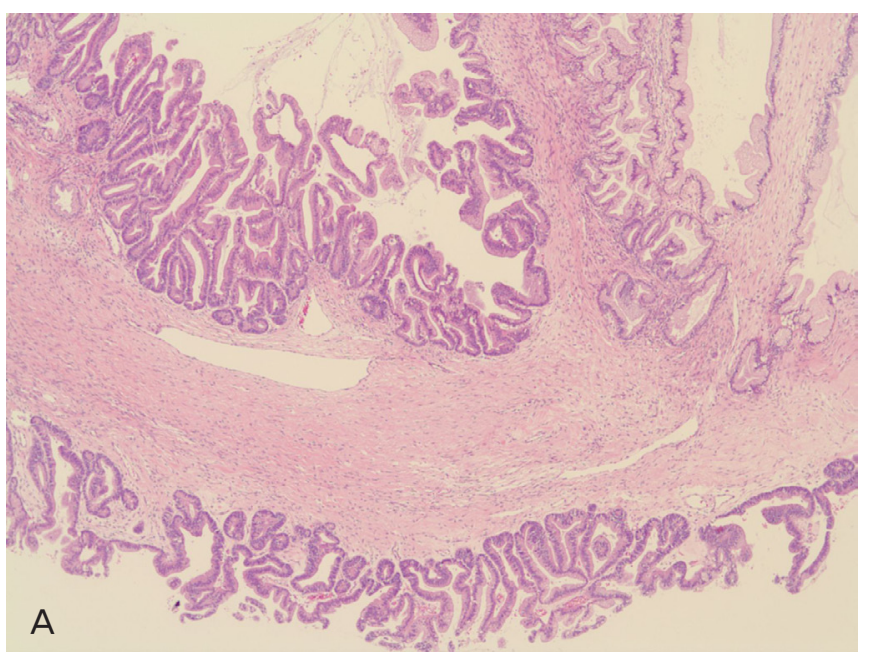

induction of general endotracheal anesthesia, $10 \mathrm{~mm}$ trocar was inserted through the midline using a Hasson technique. Two additional $5 \mathrm{~mm}$ trocars were placed on the upper abdominal quadrants bilaterally. $\mathrm{A} 0^{\circ}$ scope was placed through the midline port after $10 \mathrm{~mm} \mathrm{Hg}$ pneumoperitoneum was established. On laparoscopic examination (Fig. 3), the omentum and the surfaces of the liver, stomach, and bowel were normal. The cyst was found to be slightly adherent to the abdominal cavity. There was no free fluid in the pouch of Douglas. A large cyst arising from the left ovary was found and left salpingo-oophorectomy was performed for the ovarian mass. The mass was removed piece by piece through the umbilical trocar, widening the incision up to $2 \mathrm{~cm}$. The resected specimen weighted $3.8 \mathrm{~kg}$ and gross examination revealed a whitish tumor. The total weight of the cyst and its contents, including

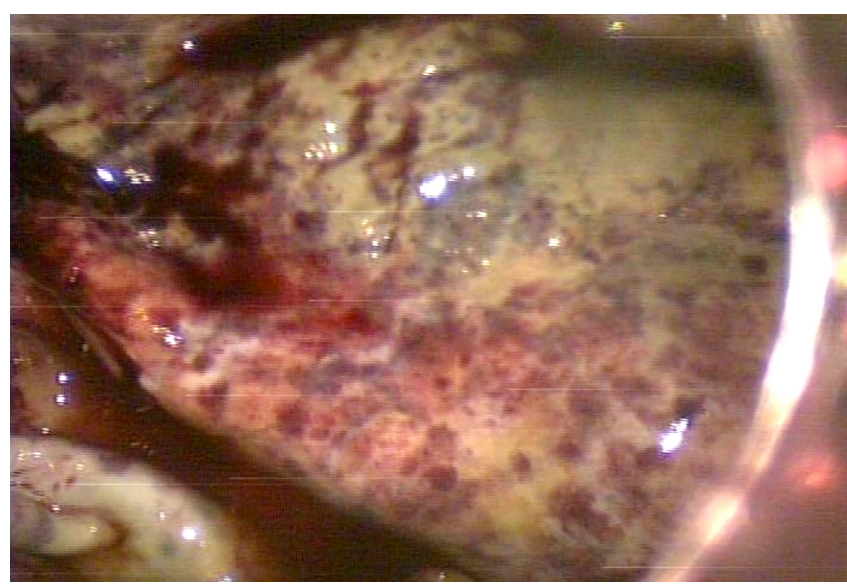

Fig. 3. Laparoscopy showing huge mass (after aspiration) in the left ovary.

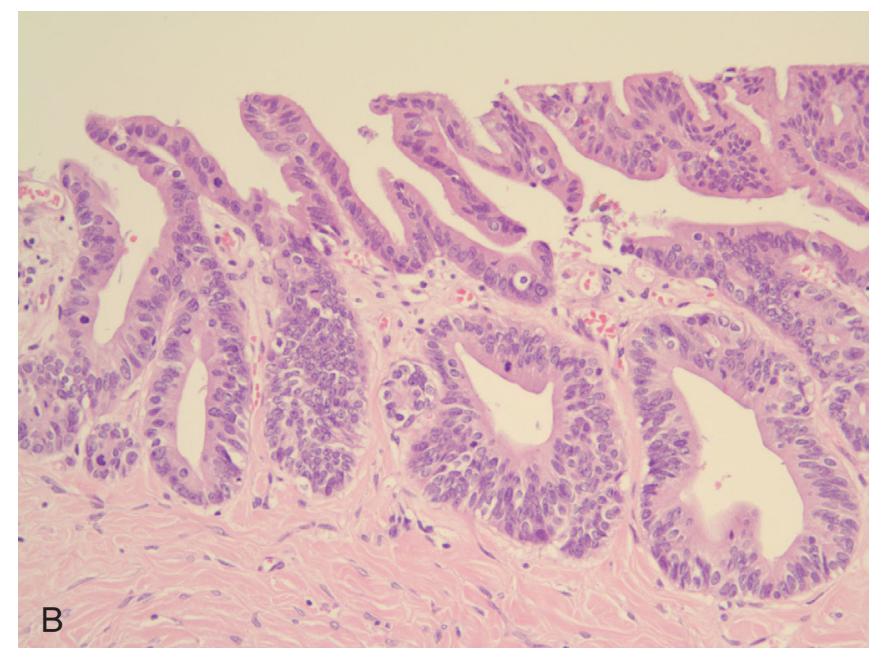

Fig. 4. (A) Microscopically, mucinous borderline tumor exhibits intracystic papillae lined by atypical mucinous epithelium. Mucinous cystadenoma component is also seen in the left upper side $(H \& E, \times 40)$. (B) High magnification of tumor cells showing atypical nuclei, mitotic figures and nuclear stratification (H\&E, $\times 200$ ). 
the fluid removed during surgery was $58 \mathrm{~kg}$. Frozen section was suspicious for a mucinous cystadenoma, but diagnosis of borderline mucinous tumor was confirmed by histology (Fig. 4). During the surgery, the patient experienced no signs of hypotension and hypoxemia, with oxygen saturation more than $99 \%$.

The postoperative course was uneventful. There were no complications, such as pneumonia, urinary tract infection, or surgical wound infection. The patient was discharged in a stable condition on postoperative day 16. Postoperative weight of the patient was $63.5 \mathrm{~kg}$.

\section{Discussion}

Giant ovarian cyst is rare finding. They have become rarer as imaging modalities improve and diagnoses are made earlier [3]. The largest ovarian tumor ever documented weighed $149 \mathrm{~kg}$ and was removed by Spohn [4] in 1905. The majority of the giant ovarian cysts which have been reported have had a mucinous histology. Mucinous cystadenomas of the ovary are known for their potential to grow to massive proportions and are often incidentally diagnosed. They are typically benign tumors accounting for $15 \%$ of ovarian neoplasms and up to $80 \%$ of all mucinous tumors [5]. Ovarian m凶ucinous cystadenomas are characteristically unilateral, only $5 \%$ presenting bilaterally, and occur principally in middle adult life and are extremely rare prior to menarche.

Increased intraabdominal pressure compromised cardiac and respiratory functions and caused supine hypotension secondary to compression of the inferior vena cava (IVC) and aorta. Supine hypotensive syndrome has been noted in pregnant women and patients with giant abdominal mass compressing the IVC to varying degrees [6]. Various clinical indicators were present, which helped identify the pathophysiologic process, including peripheral edema, dyspnea, orthopnea, decreased exercise tolerance, abdominal distension, hypotension, worsening oliguria. This syndrome is sometimes compensated for by homeostatic mechanisms, primarily appropriate intravascular volume status and sympathetic drive. Under general anesthesia, endogenous sympathetic activity is decreased, which may result in a symptomatic IVC syndrome and hypoxemia. In addition to giant abdominal cyst, positive pressure ventilation may likely contribute to the decreased venous return from chest and abdomen.

Management of giant intraabdominal cysts has traditionally required a full midline laparotomy [7]. Once the abdomen is entered and the large mass is isolated, the tumor can be resected. This can be accomplished by en bloc removal of the tumor, with or without controlled drainage of the tumor fluid. Removal of the tumor en bloc is thought by some to decrease the risk of spilling potentially malignant cells [8].

In recent years, with the minimal invasive approach becoming a widespread practice, laparoscopic excision is preferred in management of giant ovarian cyst that exceed to the umbilicus [9], but only few cases have been reported. Giant ovarian cysts that are exceeding to the umbilicus and filling the abdomen may limit the working space during laparoscopy. To establish enough working space, giant ovarian cysts can be drained before laparoscopic approach. Controlled drainage, while it may increase the risk of spillage, is thought to be a superior technique to improve exposure and prevent the phenomenon of supine hypotension syndrome [10]. In our case, the giant ovarian cyst was removed by salpingo-oophorectomy with laparoscopy after aspiration of intra-cystic fluid.

The most important potential hazard of drainage is the possibility of cell spillage into the abdominal cavity or drainage site with the potential for subsequent seeding [11]. Although several authors stated that giant ovarian cysts are usually benign, there have been reports of malignant tumors or tumors of low malignant potential [12]. The excision of giant ovarian cysts by laparotomy requires lager incision. Laparoscopic excision of giant ovarian cyst carries a risk of perforation during trocar insertion and intraabdominal spillage of the cyst content.

However, laparoscopic excision after drainage of giant ovarian cysts seems to be a safe and applicable treatment modality.

\section{References}

1. Yuen PM, Yu KM, Yip SK, Lau WC, Rogers MS, Chang A. A randomized prospective study of laparoscopy and laparotomy in the management of benign ovarian masses. Am J Obstet Gynecol 1997;177:109-14.

2. Knudsen UB, Tabor A, Mosgaard B, Andersen ES, Kjer JJ, HahnPedersen $S$, et al. Management of ovarian cysts. Acta Obstet Gynecol Scand 2004;83:1012-21.

3. Menahem S, Shvartzman P. Giant ovarian cyst mimicking ascites. J Fam Pract 1994;39:479-81.

4. Spohn AE. Multicystic ovarian tumor weighing $328 \mathrm{lb}$. Tex State J Med 1905-1906;1:273-4.

5. Malkan AD, Singh-Braich P, Panait L, Dudrick SJ. Mucinous cystadenoma of the ovary presenting as unilateral lower extremity edema. Conn Med 2009;73:517-9. 


\section{KOREAN JOURNAL OF OBSTETRICS \& GYNECOLOGY}

Su-Kon Kim, et al. Giant ovarian cyst, laparoscopic surgery

6. Tagge DU, Baron PL. Giant adrenal cyst: management and review of the literature. Am Surg 1997;63:744-6.

7. Polat C, Ozacmak ID, Yücel T, Ozmen V. Laparoscopic resection of giant mesenteric cyst. J Laparoendosc Adv Surg Tech A 2000;10:337-9.

8. Webb MJ, Decker DG, Mussey E, Williams TJ. Factor influencing survival in Stage I ovarian cancer. Am J Obstet Gynecol 1973; 116:222-8.

9. Salem HA. Laparoscopic excision of large ovarian cysts. J Ob- stet Gynaecol Res 2002;28:290-4.

10. Jones DR, Vasilakis A, Pillai L, Timberlake GA. Giant, benign, mucinous cystadenoma of the ovary: case study and literature review. Am Surg 1992;58:400-3.

11. Hunter DJ. Management of a massive ovarian cyst. Obstet Gynecol 1980;56:254-5.

12. Nakamura M, Saitoh M, Miyamoto S, Kubo Y, Tomita H, Andoh A. Case of a giant mucinous ovarian carcinoma with bone metastasis. J Obstet Gynaecol Res 2005;31:576-8.

\section{복강경수술로 치료된 거대난소종양 1 예}

\section{단국대학교 의과대학 산부인과학교실}

김수곤, 김종수, 박충학, 박진완

점액성 난소종양은 모든 난소의 신생물 중 약 $15 \%$ 를 차지하고 있으며, 거대한 변종은 매우 드물다. 의료 보급의 증가와 환자에 대한 교 육으로 최근에는 거대난소종양 $(12 \mathrm{~kg}$ 이상)은 매우 드물다. 거대난소종양에서 복강경수술은 낭종의 파열이나 수술공간의 제한 때문에 어 려울 수 있다. 이러한 제한점을 줄이기 위하여 종양내용물의 흡입 후에 복강경수술을 시행하였다. 저자들은 경계성 거대 난소종양 1 예를 경험하였기에 간단한 문헌고찰과 함께 보고하는 바이다.

중심단어: 난소, 낭종, 복강경 